\title{
IMPLEMENTASI PROGRAM FULL DAY SCHOOL DALAM PENINGKATAN KEDISIPLINAN PESERTA DIDIK DI SMP ISLAM TERPADU (IT) AS-SALAM AMBON
}

\author{
Siti Maselah Polpoke, ${ }^{1}$ Nursaid, ${ }^{2}$ Nurhasanah ${ }^{2}$ \\ ${ }^{1}$ Mahasiswa PAI FITK IAIN Ambon, ${ }^{2}$ Dosen PAI FITK IAIN Ambon \\ Email: nursaid.ng@gmail.com
}

\begin{abstract}
Abstrak SMP IT As-Salam Ambon merupakan salah satu lembaga pendidikan yang berusaha meningkatkan mutu pendidikan dengan menyelenggarakan full day school sebagai media pembentuk karakter disiplin. Tujuan penelitian ini adalah untuk mengetahui Implementasi program full day school dalam peningkatan kedisiplinan peserta didik di SMP IT As-Salam Ambon dan faktor pendukung dan penghambat dalam peningkatan kedisiplinan peserta didik di SMP IT As-salam Ambon. Jenis penelitian yang digunakan adalah deskriptif kualitatif. Subjek penelitian ini adalah kepala sekolah, guru PAI, dan guru wali kelas, dan peserta didik laki-laki. Dengan teknik pengumpulan data melalui observasi, wawancara, dan dokumentasi. Kemudian data yang sudah terkumpul di Analisis data menggunakan reduksi data, penyajian data, dan menarik kesimpulan. Penelitian ini dilaksanakan selama satu bulan sejak tanggal 18 Maret 2019 sampai dengan 18 April 2019, berlokasi di SMP IT As-Salam Ambon. Jln Kebun cengkeh Batumerah, Kecamatan sirimau, kota Ambon, Provinsi Maluku. Hasil penelitian menunjukkan bahwa, Implementasi program full day school dalam peningkatan kedisiplinan peserta didik di SMP IT As-Salam Ambon, terdapat beberapa program yang dilaksanakan di dalam kelas maupun di luar kelas, adapun program di luar kelas diantaranya: Muraja'ah, Shalat berjama'ah, Mengadakaan kultum setelah shalat asar, Pembinaan karakter pada hari jum'at dan pembinaan karakter pada hari sabtu. Faktor pendukung dan penghambat dalam peningkatan kedisiplinan peserta didik, diantaranya: Adapun faktor pendukung yaitu: Adanya pelajaran muatan lokal yang bersumber dari kurikulum yayasan, Komunikasi antara guru dan peserta didik berjalan dengan baik. Sedangkan faktor penghambat, yaitu: Lokasi rumah dan sekolah yang begitu jauh, Peserta didik kelelahan, dan Sarana prasarana yang tidak memadai.
\end{abstract}

Kata Kunci: Program Full Day School, Kedisiplinan 


\section{PENDAHULUAN}

Pendidikan merupakan suatu kebutuhan yang sangat penting bagi kehidupan umat manusia. Pendidikan dapat membentuk kepribadian peserta didik dimasa yang akan datang dan sekaligus juga mempunyai fungsi untuk mengembangkan kemampuan serta meningkatkan kualitas kehidupan manusia Indonesia dalam rangka mewujudkan tujuan Negara Kesatuan Republik Indonesia. Salah satu tujuan Negara Kesatuan Republik Indonesia yang tercantum dalam UUD 1945 adalah "Mencerdaskan kehidupan bangsa". Hal tersebut di cantumkan lebih lanjut pada batang tubuh UUD 1945 pasal 31 ayat 3 yang mengatur mengenai masalah pendidikan di Indonesia bahwa:

"Pemerintah mengusahakan dan menyelenggarakan satu pendidikan nasional, yang meningkatkan keimanan dan ketakwaan serta akhlak mulia dalam rangka mencerdaskan kehidupan bangsa, yang diatur dengan undang-undang" (UUD 1945 Pasal 31 Ayat 3).

Berdasarkan isi pasal tersebut jelas terlihat, tujuan pendidikan di Indonesia adalah untuk mencerdaskan kehidupan bangsa berarti memberikan kesempatan seluas-luasnya kepada seluruh generasi bangsa untuk mengenyam pendidikandemi menjadi bangsa yang cerdas, tangguh, dan berkarakter dalam rangka meningkatkan kualitas SDM yang ada menentukan kemajuan bangsa (Bafirman H.B, 2016).

Pendidikan karakter bukanlah hal baru dalam sejarah manusia. Orangtua, dengan berbagai cara, sejak dulu kala sebelum ada lembaga pendidikan formal yang bernama sekolah seperti sekarang, sudah berusaha mendidik anak-anak mereka menjadi anak yang baik menurut norma-norma yang berlaku dalam budaya mereka (Tim Pakar Yayasan Jati Diri Bangsa, 2011).

Anak didik sebagai gerenasi penerus bangsa, sejak dini harus dikenalkan dengan nilai-nilai yang mengatur kehidupan manusia, yang berguna bagi dirinya masing-masing, agar berlangsung tertib, efektif dan efisien. Norma-norma itu sebagai ketentuan tata tertib hidup harus dipatuhi atau ditaatinya (Hadari Nawawi, 1993). Ketaatan dan kepatuhan dalam menjalankan tata tertib kehidupan, tidak akan dirasa memberatkan bila dilaksanakan dengan kesadaran akan pentingnya dan manfaatnya. Kemauan dan kesediaan mematuhi disiplin itu datang dari dalam diri orang yang bersangkutan atau tanpa paksaan dari luar atau orang lain, khususnya diri anak didiknya. Akan tetapi dalam keadaan seseorang belum memiliki kesadaran untuk mematuhi tata tertib, yang sering dirasakannya memberatkan atau tidak mengetahui manfaat dan kegunaannya, maka diperlukan tindakan memaksakan dari luar atau dari orang bertanggung jawab dan melaksanakan atau mewujudkan sikap disiplin (Yusuf Muhammad Al Hasan, 2004).

Pentingnya pendidikan kedisiplinan, itu disebabkan karena manusia tanpa hidup dengan teratur dan disiplin maka hidupnya akan merugi. Seperti yang dijelaskan didalam Al-Qur'an Surah Al'Asr ayat 1-3:

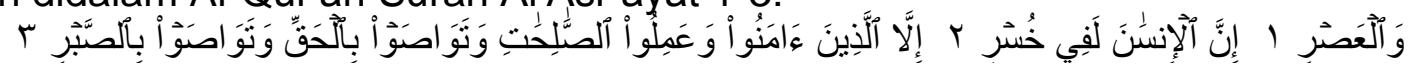
Terjemahnya:"Demi masa sesungguhnya manusia itu benar-benar dalam kerugian. Kecuali orang yang beriman dan mengerjakan amal soleh dan nasehat menasehati supaya menaati kebenaran dan nasehat menasehati supaya selalu bersabar".

Menerapkan disiplin memang sulit, tetapi Apabila disiplin itu telah terbentuk maka akan terwujudlah disiplin pribadi yang kuat, yang setelah dewasa akan diwujudkan pula dalam setiap aspek kehidupan, antara lain dalam bentuk disiplin 
kerja, disiplin mengatur keuangan rumah tangga dan disiplin dalam menunaikan perintah serta meninggalkan larangan Allah SWT. Dalam keadaan disiplin itu mampu dilaksanakan oleh semua anggota masyarakat atau warga negara, terutama berupa kepatuhan dan ketaatan terhadap ketentuan-ketentuan hidup bermasyarakat, berbangsa dan bernegara. Maka akan terwujud kedisiplinan yang bersumber dari disiplin pribadi warga negara dan pemeluknya (Hadari Nawawi, 1993).

Lembaga khususnya lembaga pendidikan seringkali menerapkan kedisiplinan baik dalam segi kelembagaan yang menerapkannya, atau pun membiasakan peserta didik untuk menerapkan kedisiplinan padanya dengan secara bertahap, upaya ini dilakukan untuk memberikan perubahan kepada siswa untuk senantiasa membiasakan diri melakukan kedisiplinan.

Penerapan disiplin dalam lingkungan pendidikan adalah menerapkan sikap peserta didik yang tunduk dan patuh terhadap aturan yang berlaku dalam lembaga pendidikan tersebut, dalam proses disiplin ini sangat erat kaitannya dengan tata tertib sekolah (Abdul Nasih Ulwan, 1992). Dalam suatu sekolah telah diterapkan tata tertib sebagai aturan dalam mengikuti proses pembelajaran, penegakan kedisiplinan di sekolah erat kaitannya dengan konsekuensi ganjaran yang diberikan sekolah terhadap peserta didik (M.Ngalim Purwanto, 2003).

Berdasarkan hasil observasi awal yang dilakukan peneliti di SMP IT As-Salam Ambon melalui pengamatan ditemukan bahwa tingkat kedisiplinan peserta didik masih dalam taraf pembenahan secara serius oleh pihak sekolah. Sekolah tersebut menerapkan program full day school dimana peserta didik menghabiskan setidaknya delapan jam untuk melakukan proses pembelajaran dan menerapkan peraturan yang disiplin. Selain itu sekolah tersebut mengoptimalkan peranan full day school, sekolah tersebut menggunakan kurikulum kementerian pendidikan nasional digabungkan dengan kurikulum Lokal, dengan menambahkan jadwal-jadwal yang bersifat keagamaan, seperti muraja'ah, shalat berjama'ah, kultum setelah shalat Asar, pembinaan karakter (liqo) pada hari sabtu yang dipimpin oleh guru-guru, pembinaan karakter khusus bagi setiap peserta didik perempuan di hari jum'at. Peningkatan kedisiplinan peserta didik perlu dilakukan karena selama ini masih saja ada pelanggaran-pelanggaran yang dilakukan oleh peserta didik. Sebagai contoh observasi terhadap peserta didik laki-laki, masih banyak peserta didik yang datang terlambat ke sekolah, ramai dikelas, berpakaian tidak sesuai dengan aturan sekolah, tidur di kelas, pulang sebelum jam pulang, tawuran, yang secara nyata hal-hal itu tertera dalam tata tertib sekolah tidak boleh dilakukan.

Pelanggaran-pelanggaran yang terjadi lebih banyak dilakukan oleh peserta didik laki-laki terutama dalam hal terlambat ke sekolah dalam sehari bisa sampai lima hingga sepuluh orang siswa bahkan lebih, dan dalam hal berpakaian yang tidak sesuai dengan aturan sekolah misalnya, bagi peserta didik laki-laki baju harus di masukkan ke dalam celana namun di lakukan sebaliknya, Dalam rangka memaksimalkan waktu luang peserta didik agar lebih bermanfaat, maka diterapkan full day school dengan tujuan pembentukan akhlak dan akidah dalam menanamkan nilai-nilai yang positif, mengembalikan manusia pada fitrah yaitu sebagai khalifah fil ardhi sebagai hamba Allah, dan juga memberikan dasar yang kuat dalam belajar di segala aspek (Observasi, 2019).

Berdasarkan uraian tersebut maka penulis merasa tertarik untuk melakukan penelitian yang berjudul "implementasi program full day school dalam peningkatan kedisiplinan peserta didik di SMP IT As-Salam Ambon". 


\section{KAJIAN TEORI}

\section{A. Program Full Day School}

\section{Sejarah full day school}

Full day school awalnya muncul pada awal tahun 1980-an di Amerika Serikat. Pada waktu itu full day school dilaksanakan untuk jenjang sekolah taman kanakkanak dan selanjutnya meluas pada jenjang yang lebih tinggi mulai dari SD sampai dengan SMA.

Munculnya sistem pendidikan full day school di Indonesia diawali dengan menjamurnya istilah sekolah unggulan sekitar tahun 1990-an, yang banyak di pelopori oleh sekolah-sekolah swasta termasuk sekolah-sekolah yang berlebel Islam (http://mufidati2318.blogspot.com, 2019). Menteri pendidikan dan kebudayaan Muhadjir Effendy menggagas sistem full day school untuk SD dan SMP, baik sekolah negeri maupun swasta. Alasannya agar anak tidak sendiri ketika orangtua mereka masih bekerja. Dengan sistem full day school ini secara perlahan anak didik akan terbangun karakternya dan tidak menjadi liar di luar sekolah ketika orangtua mereka masih sibuk bekerja.

Menteri pendidikan dan kebudayaan Muhadjir Effendy telah menetapkan peraturan Menteri Nomor 23 Tahun 2017 tentang hari sekolah yang mengatur sekolah 8 jam sehari selama 5 hari atau full day school pada 12 juni 2017 (https://kumparan.com/@kumparannews, 2019).

\section{Pengertian Full Day School}

Pendidikan merupakan usaha dari manusia untuk memperoleh ilmu pengetahuan dan meningkatkan potensi-potensi yang dimiliki agar senantiasa menjadi insan yang cerdas bermartabat. Dimana arti pendidikan disini bukan hanya transfer knowledge tapi juga merubah tingkah laku dari setiap anak untuk menjadi anak yang berkarakter. Dalam meningkatkan kualitas pendidikan, tentunya negara Indonesia mempunyai cara khusus sebagai upaya peningkatan pendidikan menuju pada tujuan pendidikan, yang sudah tertera pada Undang-Undang sistem pendidikan nasional nomor 20 tahun 2003 pasal 3, pada pasal tersebut di katakan bahwa:

"Pendidikan nasional berfungsi mengembangkan dan membentuk watak serta peradaban bangsa yang bermartabat dalam rangka mencerdaskan kehidupan bangsa, bertujuan untuk berkembangnya potensi peserta didik agar menjadi manusia yang beriman dan bertakwa kepada tuhan yang maha esa, berakhlak mulia, sehat, berilmu, cakap, kreatif, mandiri, dan menjadi warga negara yang demikratis serta bertanggung jawab" (UUD, 194531 ayat 3).

Proses pembelajaran tidak hanya dilakukan di dalam kelas saja tetapi terintegrasi dalam suatu program-program yang terencana dan tersusun rapi. Disamping itu juga telah adanya sistem pendidikan. Sistem pendidikan sangatlah penting bagi suatu lembaga pendidikan karena sistem merupakan suatu yang sangat mendasar sehingga tidak dianggap sebagai fungsi sendiri. Sistem pendidikan jugalah yang akan mengatur jalannya pendidikan disebuah negara dan akan menjadi pedoman untuk jalannya proses pendidikan tersebut. Dalam suatu sistem terdapat input, proses dan output. Lembaga pendidikan sebagaimana organisasi 
yang lain, disamping diawali visi dan misi yang jelas, umumnya memiliki keteraturan manajemen yang baik, sistem yaitu keterpaduan antara input, proses dan output sangat dibutuhkan oleh organisasi. Oleh karena itu, perlu diterapkan suatu peraturan yang jelas dan memiliki legitimasi serta memiliki kekuatan agar semua berkembang dengan baik.

Secara etimologi kata full day school berasal dari bahasa inggris, full mengandung arti penuh, dan day artinya hari. Jika digabung, akan mengandung arti sehari penuh. Sedangkan school mempunyai arti sekolah (Peter Salim, 1988). Full day school adalah suatu sistem pembelajaran yang dilakukan dalam kegiatan belajar mengajar yang dilakukan sehari penuh dengan memadukan sistem pembelajaran secara intensif yaitu dengan memberikan tambahan waktu khusus untuk pendalaman selama lima hari dan sabtu di isi dengan relaksasi atau kreativitas (http://www.sekolah indonesia.com, 2019).

Full day school adalah suatu kebutuhan waktu yang diperlukan untuk mengantisipasi terhadap perkembangan sosial budaya sebagai akibat globalisasi informasi serta percepatan perkembangan ilmu pengetahuan dan teknologi. Jadi full day school merupakan suatu kurikulum dengan seluruh isi kehidupan anak seperti belajar, bermain, beribadah, makan serta aktifitas lainnya dalam suatu rangkaian sistem pendidikan dan pengajaran yang lebih lama dibandingkan sekolah formal lainnya yaitu pukul 07:30-12:30 untuk taman kanak-kanak dan 06:45-15:30 untuk SD, SMP, SMA. Di mulainya sekolah sejak pagi hingga sore hari, sekolah lebih leluasa mengatur jam pelajaran yang mana disesuaikan dengan bobot pembelajaran dan ditambah dengan model-model pendalamannya. Sedangkan waktunya digunakan untuk program-program pembelajaran yang bernuansa informal, tidak kaku, menyenangkan bagi peserta didik dan membutuhkan kreatifitas dan inovasi seorang guru.

Pelajaran yang dianggap sulit dalam sistem full day school diletakkan pada awal masuk sekolah dan pelajaran yang lebih mudah diletakkan pada sore hari, karena pada pagi hari peserta didik masih segar dan bersemangat, dengan demikian pelajaran yang dianggap sulit oleh peserta didik akan tetap mudah di cerna karena otak masih dalam keadaan segar, namun jika mata pelajaran yang sulit tersebut diletakkan pada sore hari peserta didik akan menjadi beban dan tidak bersemangat lagi karena sudah beraktifitas seharian. Hal tersebut akan berpengaruh pada kondisi fisik dan psikis peserta didik, karena itulah dalam sekolah yang menggunakan full day school menerapkan jam istirahat dua kali sehari. Adanya penerapan full day school ini lamanya waktu pembelajaran tersebut tidak akan menjadi beban, karena sebagian waktunya digunakan untuk waktu-waktu informal. Dan pada sistem ini banyak pola dan metode dalam proses belajar mengajarnya, sistem pembelajarannya tidak top down atau monologis karena dengan metode seperti ini, maka yang akan terjadi guru mengajar dan peserta didik di ajar, guru mengetahui segalanya dan peserta didik tidak mengetahui apa-apa, guru membacakan dan murid membenarkan, atau konsep seperti itu menurut Paulo Freire adalah banking concept education, guru sebagai subjek dan peserta didik sebagai objek belaka (Moch. Ikromi, 2005).

Lebih banyaknya waktu yang tersedia di sekolah full day school memungkinkan para staf guru untuk merancang kurikulum yang dikembangkan. Dengan demikian selain materi yang wajib diajarkan sesuai peraturan dari pemerintah, terbuka kesempatan untuk menambahkan materi lain yang dipandang sesuai dengan tujuan pendidikan di lembaga tersebut. Kurikulum yang dipergunakan di sekolah full day school dirancang berdasarkan pengalaman dan masukan dari beberapa lembaga 
lain seperti penitipan anak dan kurikulum TK / SD Al-Qur'an yang telah dikembangkan dengan tetap mengacu pada kurikulum yang telah ditetapkan oleh Diknas (Wiwik Sulistyaningsih, 2008).

\section{Landasan Full Day School}

Full day school merupakan sistem yang berlandaskan pada pendidikan Islam dapat kita perhatikan beberapa definisi yang dikemukakan oleh para tokoh yaitu Zakiyah Daradjad yang mendefinisikan pendidikan Islam dengan Tarbiyah Islamiyah, yaitu sikap pembentukan manusia yang lainnya berupa perubahan sikap dan tingkah laku yang sesuai dengan petunjuk agama Islam (Zakiyah Daradjad, 2011).

"Omar Muhammad At Taumy Al Syaibany memberikan pengertian bahwa pendidikan Islam adalah usaha mengubah tingkah laku individu dalam kehidupan pribadinya atau kehidupan kemasyarakatan dan kehidupan dalam alam sekitarnya melalui proses kependidikan (Omar Muhammad At Taumy Al Syaibany, 1979).

Munadjir mengatakan bahwa pendidikan Islam adalah usaha bimbingan yang ditujukan untuk mencapai keseimbangan jasmani dan rohani menurut ajaran agama Islam, untuk mengarahkan dan mengubah tingkah laku individu untuk mencapai pertumbuhan kepribadian yang sesuai dengan ajaran Islam dalam proses kependidikan melalui latihan kecerdasan, kejiwaan, keyakinan, kemauan dan persamaan dalam seluruh aspek kehidupan manusia" (Munardji, 2004).

"H.M.Djumramsjah memberikan pengertian bahwa pendidikan Islam adalah bimbingan secara sadar dan terus-menerus yang sesuai dengan kemampuan dasar (fitrah) dan kemampuan ajarnya ( pengaruh dari luar), baik secara individual maupun kelompok sehingga manusia mampu memahami, menghayati dan mengamalkan ajaran Islam secara utuh dan benar. Ajaran Islam yang utuh meliputi: aqidah (keimanan), syari'ah (ibadah dan mu'amalah) dan akhlak (budi pekerti)" ('Djumramsjah dan Abdul Malik Karim Amrullah, 2007).

Pendidikan Islam menurut Achmad patoni adalah usaha untuk membimbing kearah pertumbuhan kepribadian peserta didik secara sistematis dan pragmatis supaya mereka hidup sesuai dengan ajaran Islam, sehingga terjalin kebahagiaan dunia dan akhirat (Achmad Patoni, 2004).

"Menurut Abuddin Nata, pendidikan Islam adalah pendidikan yang berlandaskan ajaran Islam atau pendidikan yang di jiwai oleh ajaran Islam" (Abuddin Nata, 2001).

"Akhmad Tafsir menjelaskan bahwa kata "Islam" dalam "pendidikan Islam" menunjukan warna pendidikan tertentu yaitu pendidikan yang berwarna Islam, pendidikan yang Islami yaitu pendidikan yang berdasarkan Islam" (Akhmad Tafsir, 2010).

\section{Sistem Full Day School}

Full day school menerapkan suatu konsep dasar "Integrated Activity" dan "Integrated curriculum". Model ini yang membedakan dengan sekolah pada umumnya. Dalam full day school semua program dan kegiatan peserta didik di sekolah, baik belajar, bermain, beribadah dikemas dalam sebuah sistem pendidikan. Titik tekan pada full day school adalah peserta didik selalu berprestasi belajar dalam proses pembelajaran yang berkualitas yakni diharapkan akan terjadi perubahan positif dari setiap individu peserta didik sebagai hasil dari proses dan aktifitas dalam belajar. Adapun prestasi belajar yang dimaksud terletak pada tiga ranah, yaitu:

a. Prestasi yang bersifat kognitif 
Prestasi yang bersifat kognitif seperti kemampuan peserta didik dalam mengingat, memahami, menerapkan, mengamati, menganalisa, membuat analisa dan lain sebagainya. Konkritnya, peserta didik dapat menyebutkan dan menguraikan pelajaran minggu lalu, berarti peserta didik tersebut sudah dapat dianggap berprestasi yang bersifat kognitif.

b. Prestasi yang bersifat afektif

peserta didik dapat dianggap memiliki prestasi yang bersifat afektif, jika ia sudah bisa untuk menghargai, serta dapat menerima dan menolak terhadap suatu pertanyaan dan permasalahan yang sedang mereka hadapi.

c. Prestasi yang bersifat psikomotorik

Prestasi yang bersifat psikomotorik yaitu kecakapan eksperimen verbal dan nonverbal, keterampilan bertindak dan gerak. Misalnya seorang peserta didik menerima pelajaran tentang adab sopan santun kepada orang lain, khususnya kepada orang tuanya, maka si anak sudah dianggap mampu mengaplikasikannya dalam kehidupannya (Muhibbin Syah, 2004).

Sebelum kita membahas tentang sistem full day school, kita perlu mengetahui makna sistem pembelajaran itu sendiri. Sistem adalah seperangkat elemen yang saling berhubungan satu sama lain. Adapun sistem pembelajaran adalah suatu sistem karena merupakan perpaduan berbagai elemen yang berhubungan satu sama lain. Tujuannya agar peserta didik belajar dan berhasil, yaitu bertambah pengetahuan dan keterampilan serta memiliki sikap benar. Dari sistem pembelajaran inilah akan menghasilkan sejumlah peserta didik dan lulusan yang telah meningkat pengetahuan dan keterampilannya dan berubah sikapnya menjadi lebih baik. Adapun proses inti sistem pembelajaran full day school antara lain:

a. Proses pembelajaran yang berlangsung secara aktif, kreatif, tranformatif sekaligus intensif. Sistem persekolahan dengan pola full day school mengindikasikan proses pembelajaran yang aktif dengan artian mengoptimalisasikan seluruh potensi untuk mencapai tujuan pembelajaran secara optimal baik dalam pemanfaatan sarana dan prasarana dilembaga dan mewujudkan proses pembelajaran yang kondusif demi pengembangan potensi peserta didik yang seimbang.

b. Proses pembelajaran yang dilakukan selama aktif sehari penuh tidak memforsir peserta didik pada pengkajian, penelaah yang terlalu menjenuhkan. Akan tetapi, yang memfokuskan adalah sistem relaksasinya yang santai dan lepas dari jadwal yang membosankan (http://firdausmastapala.blogspot.com, 2019).

Berdasarkan uraian diatas tadi, dapat disimpulkan bahwa konsep pengembangan dan inovasi dalam full day school adalah untuk meningkatkan mutu pendidikan di Indonesia sekarang ini dipertanyakan. maka berbagai cara dan metode dikembangkan. Penerapan full day school mengembangkan kreativitas yang mencakup tiga ranah, yaitu kognitif, afektif, dan psikomotorik serta seimbang.

\section{Program Full Day School}

Program full day school merupakan sistem pengajaran yang mengharuskan peserta didik untuk menghabiskan setidaknya delapan jam untuk melakukan proses pembelajaran disekolah. Peserta didik diajak untuk melakukan berbagai kegiatan belajar formal dan non formal dengan dukungan pengajar di sekolah.

Full day school merupakan model sekolah umum yang memadukan sistem pengajaran Islam secara intensif yaitu dengan memberi tambahan waktu khusus untuk pendalaman keagamaan siswa (http://nandasyakirah.blogspot.com, 2019).

Program-program full day school di SMP As-Salam Ambon antara lain yaitu:

a. jam sekolah 
sesuai dengan alokasi waktu dalam standar nasional tetap dilakukan pemberian materi pelajaran sesuai kurikulum standar nasional.

b. Di luar jam sekolah, dilakukan kegiatan seperti:

1. Shalat berjama'ah

SMP IT As-Salam Ambon adalah salah satu sekolah di kota Ambon yang menerapkan full day school, sehingga peserta didik berada disekolah hingga delapan jam. Dan biasanya di sekolah ini dilakukan shalat berjama'ah, baik itu shalat dzuhur maupun ashar. Shalat berjam'ah antara peserta didik putra dan juga putri dipisahkan, biasanya peserta didik putra shalat berjama'ah di mushola dan peserta didik putri shalat berjama'ah di kelas putri.

2. Kultum

Kultum adalah singkatan dari kuliah tujuh menit, kultum biasa dilakukan di SMP IT As-Salam Ambon setelah shalat ashar. Kultum biasanya dibawakan oleh peserta didik, tujuannya untuk melatih mental peserta didik dan menambah wawasan peserta didik terutama dalam khazanah Islam.

3. Pembinaan karakter bagi siswa perempuan di hari jum'at

hari jum'at peserta didik putra melakukan shalat jum'at berjama'ah di mesjid, sedangkan peserta didik putri melakukan shalat dzuhur di kelas putri, sebelum shalat dzuhur biasanya dilakukan pembinaan karakter oleh guru. Dan biasanya materi yang di bahas mengenai hal-hal penting untuk wanita dalam hukum Islam.

4. Pembinaan karakter di hari sabtu bagi seluruh peserta didik dihari sabtu

Pembinaan ini biasa disebut Liqo. Materi yang di ajarkan bukan mengenai pendidikan umum namun mengenai pendidikan Islam.

Namun peserta didik tetap diberi kesempatan untuk istirahat siang sebagaimana dilakukan dirumah. Pola hubungan antara guru dan peserta didik dan guru dengan guru dilandasi dengan bangunan akhlak yang diciptakan dan dalam konteks pendidikan serta suasana kekeluargaan.

Berdasarkan uraian tersebut dapat disimpulkan bahwa program full day school sangat bermanfaat bagi peserta didik terutama untuk membentuk akidah dan akhlak peserta didik dan menanamkan nilai-nilai positif. Namun di SMP IT As-Salam Ambon, dengan program full day school yang begitu banyak tetapi masih saja ada peserta didik yang tidak disiplin. Sehingga dalam penelitian ini peneliti ingin mencari tahu apakah program full day school dapat meningkatkan kedisiplinan peserta didik, karena secara tidak langsung program full day school sudah mendisiplinkan siswa dalam semua ranah baik kognitif, afektif maupun psikomotorik dan juga kemampuan bahasa asing (Nor Hasan, 2006).

\section{B. Kedisiplinan Peserta Didik}

\section{Pengertian Kedisiplinan Peserta Didik}

kedisiplinan berasal dari kata disiplin yang mendapat awalan ke dan akhiran an menurut kamus besar bahasa Indonesia disiplin mempunyai arti ketaatan dan kepatuhan pada aturan, tata tertib dan lain sebagainya (Tim Penyusun kamus pusat pembinaan dan pengembangan bahasa, 1997).

Allah berfirman dalam Al-Qur'an Surah An-Nisa ayat 59:

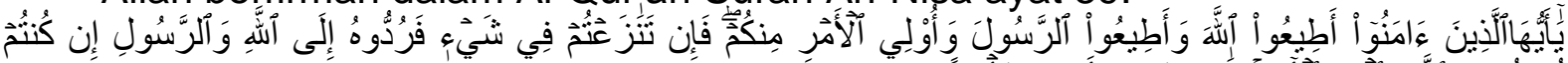

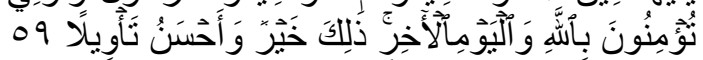

Terjemahnya:"Hai orang-orang yang beriman, taatilah Allah dan taatilah Rasul (Nya), dan ulil amri diantara kamu. Kemudian jika kamu berlainan pendapat tentang sesuatu, maka kembalikanlah ia kepada Allah (Al-Qur'an) dan Rasul (sunnahnya), jika kamu benar-benar beriman kepada Allah dan 
hari kemudian. Yang demikian itu lebih utama (bagimu) dan lebih baik akibatnya".

Allah telah menyuruh kita untuk taat kepada Allah SWT dan Rasul-Nya, disiplin adalah salah satu bentuk taat pada peraturan, terutama aturan yang telah ditetapkan Allah SWT.

Secara istilah disiplin oleh beberapa pakar diartikan sebagai berikut:

a. Keith Davis dalam R.A.Santoso Sastropoetra mengemukakan: Disiplin diartikan sebagai pengawasan terhadap diri pribadi untuk melaksanakan segala sesuatu yang telah disetujui atau diterima sebagai tanggung jawab (Santoso Sastropoetra).

b. Julie Andrews dalam Shelia Ellison dan Barbar berpendapat bahwa "Discipline is a form of life training that, once experienced and when practiced, develops an individual's ability to control themselves" (Julie andrews, 1996). (disiplin adalah suatu bentuk latihan kehidupan, suatu pengalaman yang telah dilalui dan dilakukan, mengembangkan kemampuan seseorang untuk mawas diri).

c. Soegeng Prijodarminto dalam buku "disiplin kiat menuju sukses" mengatakan : Disiplin adalah suatu kondisi yang tercipta dan terbentuk melalui proses dari serangkaian perilaku yang menunjukkan nilai-nilai ketaatan, kepatuhan, kesetiaan, keteraturan dan atau ketertiban (Soegeng Prijodarminto, 1994).

Berdasarkan definisi-definisi diatas tersebut dapat disimpulkan bahwa disiplin adalah suatu kondisi yang tercipta melalui proses latihan yang dikembangkan menjadi serangkaian perilaku yang didalamnya terdapat unsur-unsur ketaatan, kepatuhan, kesetiaan, ketertiban dan semua itu dilakukan sebagai tanggung jawab yang bertujuan untuk mawas diri.

Konsep populer dari "disiplin" sama dengan "hukuman" menurut konsep ini disiplin digunakan hanya bila anak melanggar peraturan dan perintah yang diberikan orang tua, guru atau orang dewasa yang berwenang mengatur kehidupan bermasyarakat, tempat anak itu tinggal. Hal ini sesuai dengan Sastra praja yang berpendapat bahwa: disiplin adalah penerapan budinya kearah perbaikan melalui pengarahan dan paksaan (Sastrapraja, 1987).

Sementara itu Elizabet B.Hurlock dalam perkembangan anak menjelaskan bahwa disiplin berasal dari kata yang sama dengan "discple", yakni seorang yang belajar dari atau secara suka rela mengikuti seorang pemimpin. Orang tua dan guru merupakan pemimpin dan anak merupakan murid yang belajar dari mereka cara hidup yang menuju kehidupan yang berguna dan bahagia, jadi disiplin merupakan cara masyarakat (sekolah) mengajar anak perilaku moral yang disetujui kelompok (Hurlock E.B, 1993).

Lebih lanjut Subari menegaskan bahwa disiplin adalah penurutan terhadap sesuatu peraturan dengan kesadaran sendiri untuk terciptanya tujuan peraturan itu (Subari, 1994). Sedangkan menurut Jawes Draver "disiplin" dapat diartikan kontrol terhadap kelakuan, baik oleh suatu keluasan luar ataupun oleh individu sendiri (Jawes Draver, 1986).

"Made Pidarta mendefinisikan disiplin adalah tata kerja seseorang yang sesuai dengan aturan dan norma yang telah disepakati sebelumnya. Jadi, seorang guru dikatakan berdisiplin bekerja, kalau ia bekerja dengan waktu yang tepat, taat pada petunjuk atasan, dan melakukan kewajiban sesuai dengan norma-norma yang berlaku dalam mendidik dan mengajar" (Made Pidarta, 1995). 
Berdasarkan berbagai pendapat diatas jelaslah bahwa disiplin terkait dengan peraturan yang berlaku di lingkungan hidup seseorang, dan seseorang dikatakan berdisiplin jika seseorang itu sepenuhnya patuh pada peraturan atau norma-norma. Disiplin mencakup totalitas gerak rohani dan jasmani masa yang konsisten terus menerus tunduk dan patuh tanpa reserve melaksanakan segala perintah atau peraturan. Totalitas kepatuhan meliputi niat, akal, pikiran, kata-katadan perbuatan di dalam diri setiap insan. Penyelewengan atas garis-garis haluan manusia yang telah ditetapkan, pasti akan mengakibatkan kekeroposan dan ketidakstabilan dalam keseluruhan sistem dan struktur masa tersebut.

Seseorang dikatakan menjalankan ketertiban jika orang tersebut menjalankan peraturan karena pengaruh dari luar misalnya guru, kepala sekolah, orang tua dan lain-lain. Sedangkan seseorang dikatakan bersiasat jika orang tersebut menjalankan peraturan yang harus dijalankan dengan mengingat kepentingan umum dan juga kepentingan diri sendiri (Subari, 1994).

\section{Faktor-Faktor Yang Mempengaruhi Kedisiplinan Peserta Didik}

Kedisiplinan bukan merupakan sesuatu yang terjadi secara otomatis atau spontan pada diri seseorang melainkan sikap tersebut terbentuk atas dasar beberapa faktor yang mempengaruhinya.

Adapun faktor-faktor tersebut yakni :

a. Faktor Intern

Yaitu faktor yang terdapat dalam diri orang yang bersangkutan, faktor-faktor tersebut meliputi

1. Faktor Pembawaan

Menurut aliran nativisme bahwa nasib anak itu sebagian besar berpusat pada pembawaannya sedangkan pengaruh lingkungan hidupnya sedikit saja. Baik buruknya perkembangan anak sepenuhnya bergantung pada pembawaannya (Muhammad Kasiran, 1983). Pendapat itu menunjukan bahwa salah satu faktor yang menyebabkan orang bersikap disiplin adalah pembawaan yang merupakan warisan dari keturunannya seperti yang dikatakan oleh Jonh Brierly, "Heridity and environment interact in the production of each dan every character" (John Brierly, 1994). (keturunan dan lingkungan berpengaruh dalam menghasilkan setiap dan tiaptiap perilaku).

2. Faktor Kesadaran

Kesadaran adalah hati yang telah terbuka atas pikiran yang telah terbuka tentang apa yang telah dikerjakan (Djoko Widagdho, Dkk, 1994). Disiplin akan lebih mudah ditegakkan bilamana timbul dari kesadaran setiap insan, untuk selalu mau bertindak taat, patuh, tertib, teratur bukan karena ada tekanan atau paksaan dari luar (Soegeng Prijodarmanto, 1994). Berdasarkan pernyataan tersebut menunjukan jika seseorang memiliki kesadaran atau pikirannya telah terbuka untuk melaksanakan disiplin maka ia pun akan melakukannya.

3. Faktor Minat dan Motivasi

Minat adalah suatu perangkat manfaat yang terdiri dari kombinasi, perpaduan dan campuran dari perasaan-perasaan, harapan, prasangka, cemas, takut dan kecenderungan-kecenderungan lain yang bisa mengarahkan individu kepada suatu pilihan tertentu (Dewa Ketut Sukardi). Sedangkan Motivasi adalah suatu dorongan atau kehendak yang menyebabkan seseorang melakukan sesuatu perbuatan tertentu untuk mencapai tujuan tertentu (Tursan Hakim, 2001). Disiplin minat dan motivasi sangat berpengaruh untuk meningkatkan keinginan yang ada dalam diri seseorang. Jika minat dan motivasi seseorang dalam berdisiplin sangat kuat maka dengan sendirinya ia akan berperilaku disiplin tanpa menunggu dorongan dari luar. 


\section{Faktor Pengaruh Pola Pikir}

"Ahmad Amin dalam bukunya "Etika" mengatakan bahwa ahli ilmu jiwa menetapkan bahwa pikiran itu tentu mendahului perbuatan, maka perbuatan berkehendak itu dapat dilakukan setelah berpikir" (Ahmad Amin, 1975).

Pola pikir yang telah ada terlebih dahulu sebelum tertuang dalam perbuatan sangat berpengaruh dalam melakukan suatu kehendak atau keinginan. Jika orang mulai berpikir akan pentingnya disiplin maka ia akan melakukannya.

b. Faktor Ekstern

Yaitu faktor yang berada di luar diri orang yang bersangkutan. Faktor ini meliputi :

1. Contoh atau teladan

Teladan atau modelling adalah contoh perbuatan dan tindakan sehari-hari dari seseorang yang berpengaruh (Charles Schaefer, 1980). Keteladanan merupakan salah satu teknik pendidikan yang efektif dan sukses, karena teladan itu menyediakan isyarat-isyarat non verbal sebagai contoh yang jelas untuk ditiru. Mengarang buku pendidikan adalah mudah begitu juga menyusun suatu metodologi pendidikan, namun hal itu masih tetap hanya akan merupakan tulisan di atas kertas, selama tidak bisa terjemah menjadi kenyataan yang hidup (Muhammad Qutub, 1993).

Berdasarkan uraian tersebut menunjukkan bahwa teladan sangat berpengaruh dalam pembentukan tingkah laku.

2. Nasihat

jiwa manusia terdapat pembawaan untuk terpengaruh oleh kata-kata yang didengar (Muhammad Qutub, 1993). Oleh karena itu teladan dirasa kurang cukup untuk memengaruhi seseorang agar berdisiplin. Menasihati berarti memberi saransaran percobaan untuk memecahkan suatu masalah berdasarkan keahlian atau pandangan yang objektif (Charles Schaefer, 2000). Dalam bahasa inggris nasihat disebut advice yaitu opinion about what to do, how to behave (As Horby, 1986), pendapat tentang apa yang harus dilakukan, bagaimana bertingkah laku.

3. Faktor latihan

Melatih berarti memberi anak-anak pelajaran khusus atau bimbingan untuk mempersiapkan mereka menghadapi kejadian atau masalah-masalah yang akan datang (Charles Schaefer, 2000). Latihan melakukan sesuatu dengan disiplin yang baik dapat dilakukan sejak kecil sehingga lama-kelamaan akan terbiasa melaksanakannya, jadi dalam hal ini sikap disiplin yang ada pada seseorang selain berasal dari pembawaan bisa dikembangkan melalui latihan.

4. Faktor lingkungan

Salah satu yang menunjang keberhasilan pendidikan yaitu lingkungan, demikian juga dengan disiplin. Lingkungan sekolahan misalnya dalam kesehariannya siswa terbiasa melakukan kegiatan yang tertib dan teratur karena lingkungan yang mendukung serta memaksakan untuk berdisiplin.

5. Faktor pengaruh kelompok

Pembawaan dan latihan memang sangat berpengaruh dalam kedisiplinan, pembawaan dari lahir yang ditunjang latihan bisa dikembangkan jika terpengaruh oleh suatu kelompok yang berdisiplin, tapi pembawaan yang baik ditunjang dengan latihan yang baik bisa jadi tidak baik jika terpengaruh oleh suatu kelompok yang tidak baik demikian juga sebaliknya.

"Menurut Zakiyah Daradjat dalam buku "Ilmu Jiwa Agama" bahwa para remaja sangat memperhatikan penerimaan sosial dari teman-temannya, ingin diperhatikan dan mendapat tempat dalam kelompok teman-temannya itulah 
yang mendorong remaja meniru apayang dibuat, dipakai dan dilakukan teman-temannya" (Zakiyah Daradjat, 1970).

Apa yang dikemukakan Zakiyah Daradjat menunjukkan bahwa pengaruh kelompok lebih kuat dibanding yang lain, karena tidak dapat disangkal bahwa manusia sebagai makhluk sosial dan bersosialisasi merupakan kebutuhan yang tidak dapat dihindari.

\section{Bentuk-bentuk kedisiplinan peserta didik}

Kedisiplinan peserta didik dalam lingkup pendidikan formal terdiri dari beberapa bentuk-bentuk seperti yang di kemukakan oleh Aan Sulono sebagai berikut: 1) hadir diruangan pada waktunya, 2) Tata pergaulan di sekolah, 3) Mengikuti kegiatan ekstrakulikuler, 4) belajar dirumah (Aan Sulono, 1988).

Berdasarkan bentuk-bentuk kedisiplinan yang dikemukakan di atas dapat diberikan pengertian sebagai berikut:

a. Hadir diruangan pada waktunya

Kedisiplinan hadir di ruangan tepat waktu atau tiba di sekolah tepat pada waktunya adalah salah satu betuk kedisiplinan yang sangat sering dijumpai di lembaga-lembaga pendidikan, penujukan waktu memang sangat penting dalam kehidupan sehari-hari begitu pula dengan peserta didik di sekolah mereka. Melaksanakan aturan dalam hal ini adalah ketepatan pada waktu akan berdampak pada kehidupan keseharian mereka, terbiasa untuk bangun pagi dan mengatur waktu untuk tepat sampai pada sekolah akan membuat kedisiplinan mereka meningkat, begitu pula sebaliknya mereka yang terlambat atau tidak mementingkan disiplin akan terbiasa dalam menyia-nyiakan waktu, terlambat ke sekolah, mereka tidak akan bisa mendapatkan kesuksesan dalam memperoleh ilmu di sekolah.

b. Tata pergaulan di sekolah

Sikap disiplin dalam tata pergaulan disekolah ini dapat diwujudkan dengan tindakan-tindakan menghormati semua orang yang bergabung dalam sekolah, menghormati pendapat mereka, menjaga diri dari perbuatan-perbuatan dan sikap yang bertentangan dengan agama, saling menolong dalam hal yang terpuji.

c. Kegiatan ekstrakulikuler

Kegiatan ekstrakulikuler merupakan salah satu dari serentetan program sekolah, maka peserta didik juga di tuntut berdisiplin dan aktif dalam melaksanakan ekstrakulikuler di sekolah tersebut dalam kegiatan ini sangat jelas dapat dilihat bagaimana siswa dapat berdisiplin tanpa adanya guru yang melihat mereka dalam melaksanakan kegiatan, kegiatan ekstrakulikuler adalah kegiatan yang dilakukan pada jam sekolah dan bertujuan untuk memperluas pengetahuan peserta didik.

d. Belajar di rumah

Disiplin belajar di rumah peserta didik menjadi lebih ingat terhadap pelajaran yang telah dipelajari dan lebih siap untuk menghadapi pelajaran yang akan dihadapi atau yang akan diberikan oleh gurunya, sehingga peserta didik akan lebih paham terhadap pelajaran yang diberikan di sekolah.

Rata-rata sekolah memiliki peraturan dan tata tertib yang harus dilaksanakan dan dipatuhi oleh semua peserta didik. Peraturan yang di buat sekolah merupakan kebijakan sekolah yang tertulis dan berlaku sebagai standar untuk tingkah laku peserta didik sehingga peserta didik mengetahui batasan-batasan dalam bertingkah laku. Dalam penanaman kedisiplinan terhadap peserta didik perlu adanya perencanaan serta aturan yang dibuat untuk pembinaan kedisiplinan. Rencana kedisiplinan akan menjadi efektif jika diterapkan secara universal. Disiplin selain berhubungan dengan penguasaan diri juga dengan rasa tanggung jawab, orang yang disiplin cenderung patuh, mendukung dan mempertahankan tegaknya 
peraturan dan nilai-nilai yang berlaku, untuk merealisasikan kedisiplinan sekolah maka kedisiplinan sekolah dapat berupa:

1. Disiplin menaati tata tertib sekolah

Tata tertib sekolah dibuat dan disusun dengan tujuan menolong peserta didik menjadi lebih mandiri dan bertanggung jawab. Kedisiplinan di sekolah erat kaitannya dengan menaati tata tertib pada dasarnya menjadi alat pendidikan bagi pengembangan kepribadian yang lebih dewasa, berkenaan dengan ini, jika ada guru atau peserta didik yang melanggar mereka diberi sanksi yang mendidik, bila ada yang melanggar berulang kali diberi sanksi yang lebih berat dan lain sebagainya.

2. Disiplin waktu sekolah

Waktu adalah sesuatu yang tidak ternilai harganya. Karena waktu merupakan masa yang berjalan sehingga orang yang tidak memanfaatkan waktu dengan sebaik-baiknya merupakan bagian yang integral dari perilaku disiplin. Oleh karena itu disiplin waktu dalam sekolah tidak hanya bagi guru namun juga terhadap peserta didik, peserta didik yang tidak memanfaatkan waktunya akan tertinggal dalam segala kegiatan di sekolah.

3. Disiplin dalam berpakaian

Seseorang dapat memakai pakaian sesuai dengan keinginannya, namun dalam hal-hal tertentu berpakaian juga harus diatur, terlebih dalam lingkungan sekolah. Melatih peserta didik untuk berseragam adalah mendidik karena hal ini akan menciptakan jati diri peserta didik yang bersih, peduli diri sendiri (Soegarda Poerbakawatja, 2007).

Bentuk-bentuk kedisiplinan peserta didik di sekolah ini pada hakikatnya memang sangat penting dalam ruang lingkup lembaga pendidikan setiap bentuk kedisiplinan tentunya memiliki beberapa perbedaan ini tidak lain untuk menunjukan ciri khusus dari lembaga pendidikan tersebut, namun demikian tujuan dari bentukbentuk kedisiplinan tersebut tetap sama yakni untuk meningkatkan kedisiplinan peserta didik di sekolah tersebut. Dalam proses pembelajaran disekolah sering dijumpai kenakalan atau pelanggaran yang dilakukan peserta didik, misalnya membolos, terlambat, membuat keributan, tidak mengerjakan tugas dan sebagainya. Hal-hal tersebut merupakan salah satu cerminan dari kurangnya disiplin peserta didik. Untuk mengatasinya pihak sekolah membuat peraturan, tata tertib dan disertai sanksi bagi pelanggarnya, dengan berbagai pertimbangan yang tidak memberatkan peserta didik dan untuk kebaikan peserta didik itu sendiri yaitu agar peserta didik dapat disiplin dalam kegiatan belajar mengajar.

Bentuk disiplin lembaga pendidikan dapat diukur melalui pelaksanaan tata tertib yang ada di sekolah tersebut, semakin sedikit pelanggaran tata tertib yang dilaksanakan oleh peserta didik menunjukan semakin meningkat pula kedisiplinan yang dilakukan oleh peserta didik, karena ukuran kedisiplinan itu berbeda-beda dalam setiap lembaga pendidikan itu karena peraturan tata tertib yang dimiliki setiap sekolah juga berbeda walaupun sebenarnya tujuan dari kedisiplinan tesebut adalah sama.

Berdasarkan beberapa uraian tersebut dapat disimpulkan bahwa bentuk kedisiplinan terwujud dari pelaksanaan tata tertib, namun sampai saat ini meskipun tata tertib di SMP IT As-Salam Ambon wajib dilakukan, masih saja terjadi pelanggaran yang dilakukan oleh peserta didik, seperti disiplin waktu sekolah dan disiplin dalam berpakaian, karena masih ada saja peserta didik yang datang terlambat dan juga berpakaian tidak sesuai dengan aturan sekolah, dalam penelitian ini peneliti ingin mencari tahu apakah program full day school dapat meningkatkan kedisiplinan peserta didik, karena secara tidak langsung kedisiplinan berfungsi 
mendukung terlaksananya proses dan kegiatan pendidikan agar berjalan lancar dan memberi pengaruh bagi terciptanya sekolah sebagai lingkungan pendidikan yang kondusif bagi kegiatan pembelajaran.

\section{PEMBAHASAN}

Dari penulisan yang telah dilaksanakan oleh peneliti dengan judul "Implementasi program full day school dalam peningkatan kedisiplinan peserta didik di SMP IT As-Salam Ambon". Berdasarkan data yang diperoleh peneliti melalui observasi dan dokumentasi (foto dan rekaman), maka peneliti akan menganalisa temuan yang ada dan memodifikasi dari yang ada. Keterangan dalam teknik analisa data penulisan ini, peneliti menggunakan analisisis deskriptif kualitatif dan data yang diperoleh melalui observasi, wawancara dan dokumentasi dari pihak-pihak yang mengetahui tentang data yang penulis butuhkan.

Adapun data yang akan dipaparkan dan dianalisa oleh peneliti sesuai dengan rumusan penulisan di atas untuk lebih jelasnya peneliti akan membahasnya.

\section{Implementasi program full day school dalam peningkatan kedisiplinan peserta didik di SMP IT As-Salam Ambon}

Full day school merupakan program pendidikan yang seluruh aktifitas berada di sekolah ( sepanjang hari) dengan ciri integrated activity dan integrated curriculum. Dengan pendekatan ini maka seluruh program dan aktifitas anak di sekolah mulai dari belajar, bermain, makan dan ibadah dikemas dalam suatu sistem pendidikan. Dengan sistem ini pula diharapkan mampu memberikan nilai-nilai kehidupan yang islami pada anak didik secara utuh dan terintegrasi dalam tujuan pendidikan. Konsep pendidikan yang dijalankan sebenarnya adalah konsep effective school, yakni bagaimana menciptakan lingkungan yang efektif bagi anak didik. Sebagai konsekuensinya, anak-anak didik diberi waktu lebih banyak di lingkungan sekolah.

Program full day school merupakan sistem pengajaran yang mengharuskan siswa untuk menghabiskan setidaknya delapan jam untuk melakukan proses pembelajaran disekolah. Peserta didik diajak untuk melakukan berbagai kegiatan belajar formal dan non formal dengan dukungan pengajar di sekolah.

Full day school merupakan model sekolah umum yang memadukan sistem pengajaran Islam secara intensif yaitu dengan memberi tambahan waktu khusus untuk pendalaman keagamaan peserta didik.

Adapun pelaksanaan program full day school SMP IT As-Salam Ambon yang bersumber dari Al-qur'an, penerapan program full day school dibagi dalam dua macam, yaitu kegiatan di luar pembelajaran dan kegiatan di dalam pembelajaran. Adapun Kegiatan di luar pembelajaran diantaranya muraja'ah, shalat berjama'ah, kultum, pembinaan karakter fiqih wanita dan liqo. Sedangkan kegiatan di dalam pembelajaran diantaranya tahfidz dan tahsin Qur'an. Diterapkannya full day school ini otomatis peserta didik lebih banyak menghabiskan waktunya dengan guru-guru dan teman-temannya di sekolah sehingga hubungan guru dengan peserta didik tidak sekedar saat proses pembelajaran di kelas saja, akan tetapi guru juga bisa membimbing dan menjadi figur yang dekat dengan peserta didik.

Pendidikan karakter tidak hanya mengajarkan mana yang benar dan mana yang salah kepada peserta didik, tetapi juga menanamkan kebiasaan, tentang yang lebih baik sehingga peserta didik paham, mampu merasakan, dan mau melakukannya. Dengan demikian pendidikan karakter membawa misi yang sama dengan pendidikan akhlak atau pendidikan moral. Penanaman nilai-nilai karakter yang bisa dilakukan melalui proses pembelajaran dan kegiatan lainnya dengan memberikan motivasi dan nasehat kepada peserta didik. Kemudian peserta didik 
mampu merasakan dan mampu membedakan mana yang benar untuk dilaksanakan dan mana yang salah untuk dihindari.

\section{Faktor-Faktor Pendukung dan Penghambat dalam Peningkatan Kedisiplinan Peserta Didik di SMP IT As-Salam Ambon}

Kedisiplinan bukan merupakan sesuatu yang terjadi secara otomatis atau spontan pada diri seseorang melainkan sikap tersebut terbentuk atas dasar beberapa faktor yang mempengaruhinya.

Adapun faktor-faktor tersebut yakni :

a. Faktor Intern

Yaitu faktor yang terdapat dalam diri orang yang bersangkutan, faktor-faktor tersebut meliputi

1. Faktor Pembawaan

Menurut aliran nativisme bahwa nasib anak itu sebagian besar berpusat pada pembawaannya sedangkan pengaruh lingkungan hidupnya sedikit saja. Baik buruknya perkembangan anak sepenuhnya bergantung pada pembawaannya. Pendapat itu menunjukan bahwa salah satu faktor yang menyebabkan orang bersikap disiplin adalah pembawaan yang merupakan warisan dari keturunannya seperti yang dikatakan oleh Jonh Brierly, "Heridity and environment interact in the production of each dan every character". (keturunan dan lingkungan berpengaruh dalam menghasilkan setiap dan tiap-tiap perilaku).

2. Faktor Kesadaran

Kesadaran adalah hati yang telah terbuka atas pikiran yang telahterbuka tentangapa yang telah dikerjakan. Disiplin akan lebih mudah ditegakkan bilamana timbul dari kesadaran setiap insan, untuk selalu mau bertindak taat, patuh, tertib, teratur bukan karena ada tekanan atau paksaan dari luar. Berdasarkan pernyataan tersebut menunjukan jika seseorang memiliki kesadaran atau pikirannya telah terbuka untuk melaksanakan disiplin maka ia pun akan melakukannya.

3. Faktor Minat dan Motivasi

Minat adalah suatu perangkat manfaat yang terdiri dari kombinasi, perpaduan dan campuran dari perasaan-perasaan, harapan, prasangka, cemas, takut dan kecenderungan-kecenderungan lain yang bisa mengarahkan individu kepada suatu pilihan tertentu. Sedangkan Motivasi adalah suatu dorongan atau kehendak yang menyebabkan seseorang melakukan sesuatu perbuatan tertentu untuk mencapai tujuan tertentu. Disiplin minat dan motivasi sangat berpengaruh untuk meningkatkan keinginan yang ada dalam diri seseorang. Jika minat dan motivasi seseorang dalam berdisiplin sangat kuat maka dengan sendirinya ia akan berperilaku disiplin tanpa menunggu dorongan dari luar.

4. Faktor Pengaruh Pola Pikir

Pola pikir yang telah ada terlebih dahulu sebelum tertuang dalam perbuatan sangat berpengaruh dalam melakukan suatu kehendak atau keinginan. Jika orang mulai berpikir akan pentingnya disiplin maka ia akan melakukannya.

b. Faktor Ekstern

Yaitu faktor yang berada di luar diri orang yang bersangkutan. Faktor ini meliputi :

1. Contoh atau teladan

Teladan atau modelling adalah contoh perbuatan dan tindakan sehari-haridari seseorang yang berpengaruh. Keteladanan merupakan salah satu teknik pendidikan yang efektif dan sukses, karena teladan itu menyediakan isyarat-isyarat non verbal sebagai contoh yang jelas untuk ditiru.Mengarang buku pendidikan adalah mudah begitu juga menyusun suatu metodologi pendidikan, namun hal itu masih tetap 
hanya akan merupakan tulisan di atas kertas, selama tidak bisa terjemah menjadi kenyataan yang hidup.

Berdasarkan uraian tersebut menunjukkan bahwa teladan sangat berpengaruh dalam pembentukan tingkah laku.

2. Nasihat

jiwa manusia terdapat pembawaan untuk terpengaruh oleh kata-kata yang didengar. Oleh karena itu teladan dirasa kurang cukup untuk memengaruhi seseorang agar berdisiplin. Menasihati berarti memberi saran-saran percobaan untuk memecahkan suatu masalah berdasarkan keahlian atau pandangan yang objektif. Dalam bahasa inggris nasihat disebut advice yaitu opinion about what to do, how to behave, pendapat tentang apa yang harus dilakukan, bagaimana bertingkah laku.

3. Faktor latihan

Melatih berarti memberi anak-anak pelajaran khusus atau bimbingan untuk mempersiapkan mereka menghadapi kejadian atau masalah-masalah yang akan datang. Latihan melakukan sesuatu dengan disiplin yang baik dapat dilakukan sejak kecil sehingga lama-kelamaan akan terbiasa melaksanakannya, jadi dalam hal ini sikap disiplin yang ada pada seseorang selain berasal dari pembawaan bisa dikembangkan melalui latihan.

4. Faktor lingkungan

Salah satu yang menunjang keberhasilan pendidikan yaitu lingkungan, demikian juga dengan disiplin. Lingkungan sekolahan misalnya dalam kesehariannya peserta didik terbiasa melakukan kegiatan yang tertib dan teratur karena lingkungan yang mendukung serta memaksakan untuk berdisiplin.

5. Faktor pengaruh kelompok

Pembawaan dan latihan memang sangat berpengaruh dalam kedisiplinan, pembawaan dari lahir yang ditunjang latihan bisa dikembangkan jika terpengaruh oleh suatu kelompok yang berdisiplin, tapi pembawaan yang baik ditunjang dengan latihan yang baik bisa jadi tidak baik jika terpengaruh oleh suatu kelompok yang tidak baik demikian juga sebaliknya.

Dalam pelaksanaan program full day school di SMP IT As-Salam Ambon terdapat faktor pendukung dalam peningkatan kedisiplinan peserta didik antara lain yaitu, adanya pelajaran muatan lokal yang ditambahkan dari kurikulum yayasan. Pelajaran muatan lokal itu sendiri terdiri dari mata pelajaran tahfidz dan tahsin Qur'an, kemudian Komunikasi antara guru dan peserta didik terjalin dengan baik, peserta didik tidak sungkan berbicara dengan guru dan begitu pula guru yang memberi ruang untuk peserta didik dapat berkomunikasi tanpa rasa takut.

Sedangkan faktor penghambat dalam peningkatan disiplin peserta didik yaitu, lokasi rumah dan sekolah yang begitu jauh, banyak peserta didik yang mengeluh kelelahan karena harus sekolah dari pagi hingga sore hari ini, sarana dan prasarana di sekolah pun tidak memadai, tidak adanya gedung mushola sendiri karena mushola yang sekarang di pakai untuk sholat adalah ruangan kelas. Ruangan kelas yang tidak cukup untuk peserta didik karena pada semestinya peserta didik laki-laki dipisahkan kelasnya dengan peserta didik perempuan. 


\section{DAFTAR PUSTAKA}

[1] Abdul Malik Karim Amrullah, Djumramsjah. Pendidikan Islam : Menggali Tradisi Meneguhkan Eksistensi, Malang : UIN Malang Press, 2007.

[2] Al Hasan, Yusuf Muhammad. Pendidikan Anak Dalam Islam, Jakarta :Darul Haq, 2004.

[3] Amin, Ahmad. Etika, Jakarta : Bulan Bintang, 1975.

[4] Andrews, Julie. discipline, dalam shelia ellison and barbara an barnet ph.d, 365 ways to help your children grow, sourcebook, naperville, llinois, 1996.

[5] At Taumy Al Syaibany, Omar Muhammad. Filsafat Pendidikan Islam: Terjemah Hasan Langgulung, Jakarta : Bulan Bintang, 1979.

[6] Brierly, John. Give Me A Child Until The Is Seven, Brain Stadies Early Childhood Education, The Falmes Perss, London And Washington DC, 1994.

[7] Daradjad, Zakiyah. IImu Pendidikan Islam, Jakarta : Bumi Aksara, 2011.

[8] Daradjat, Zakiyah. Ilmu Jiwa Agama, Jakarta : Bulan Bintang, 1970.

[9] Djoko Widagdho, Dkk. Ilmu Budaya Dasar, Jakarta : Bumi Aksara, 1994.

[10] Draver, Jawes. Kamus Psikologi, Jakarta : Bina Aksara, 1986.

[11] E.B, Hurlock. Perkembangan Anak, Jakarta : Erlangga, 1993.

[12] H.B., Bafirman. Pembentukan Karakter Siswa Melalui Pembelajaran Penjasorkes, Jakarta : Kencana, 2016.

[13] Hakim, Tursan. Belajar Secara Efektif, Jakarta : Puspa Swara, 2001.

[14] Hasan, Nor. Full day School, (Model Alternatif Pembelajaran bahasa Asing), Jurnal Pendidikan Tadris. Vol 1.Nol, 2006.

[15] Horby, As. Oxford Advanced Distionary Of Current English, Oxford University Press, Oxford, 1986.

[16] Http://ejournal. Sunan.ampel.ac.id/index.php/antologi/article/view/318/257

[17] http://firdausmastapala.blogspot.com/2019/01/problematika-pendidikanmodern.html

[18] Http://mufidati2318.blogspot.com/?m=1

[19] http://nandasyakirah.blogspot.com/2017/03/program full-day-school.html?m=1

[20] Http:/Www.Sekolah Indonesia.com/Alirsyad//Smu/Muqaddimah/Htm

[21] Https://m.Kumparan.com/@Kumparannews/ini-isi-peraturan-mendikbudtentang-full-day-school

[22] Ikromi, Moch. Pengembangan Manajemen Sistem Pendidikan, tesis Universitas Islam Negeri (UIN) Malang, 2005.

[23] Kasiran, Muhammad. IImu Jiwa Perkembangan, Usaha Nasional, Surabaya : 1983.

[24] Munardji, IImu Pendidikan Islam, Jakarta : Bina IImu, 2004.

[25] Nata, Abuddin. Filsafat Pendidikan Islam, Jakarta : Gaya Media Pratama, 
2001.

[26] Nawawi, Hadari. Pendidikan Dalam Islam, Surabaya : Al-Ikhlas, 1993.

[27] Ngalim Purwanto, M. Pendidikan Teoritis dan Praktis, Bandung : PT. Remaja Rosdakarya, 2003.

[28] Patoni, Achmad. Metodologi Pendidikan Agama Islam, Jakarta : Bina IImu, 2004.

[29] Pidarta, Made. Peranan Kepala Sekolah Pada Pendidikan Dasar, Jakarta : Grafindo, 1995.

[30] Poerbakawatja, Soegarda. Ensiklopedi Pendidikan, Jakarta: Gunung Agung, 2007.

[31] Prijodarmanto, Soegeng. Disiplin Kiat Menuju Sukses,Jakarta: Pradnya Paramita, 1994.

[32] Qutb, Muhammad. Sistem Pendidikan Islam, Bandung : PT. Al-Ma'arif, 1993.

[33] Saddam, Husein Sahrawi Saimima. "ROLE OF THE TEACHER'S DISCUSSION SUBJECTS IN ENHANCING THE COMPETENCE OF ISLAMIC RELIGIOUS EDUCATION TEACHERS." al-Iltizam: Jurnal Pendidikan Agama Islam 4.1 (2019): 104-110.

[34] Salim, Peter. Advanced English-Indonesia Distonary, Jakarta : Modern English Press, 1988.

[35] Sastrapraja, Kamus Istilah Pendidikan dan umum, Usaha Nasional, Surabaya : 1987.

[36] Sastropoetra, Santoso. partisipasi, komunikasi, persuasi dan disiplin dalam pembangunan nasional, bandung :Alumni.

[37] Schaefer, Charles. Bagaimana Membimbing, Mendidik dan Mendisiplinkan Anak Secara Efektif, Jakarta : Restu Agung, 2000.

[38] Schaefer, Charles. Cara Efektif Mendidik dan Mendisiplin Anak, Jakarta : Mitra Utama, 1980.

[39] Subari, Supervisi Pendidikan Dalam Rangka Perbaikan Situasi Mengajar, Jakarta : Bumi Aksara, 1994.

[40] Sukardi, Dewa Ketut. Bimbingan Karir Di Sekolah-Sekolah, Jakarta : CV. Ghalia Indonesia.

[41] Sulistyaningsih, Wiwik. Full Day School \& Optimalisasi Perkembangan Anak, Yogyakarta : Paradigma Indonesia, 2008.

[42] Sulono, Aan. Pendidikan Moral Pancasila, Jakarta: Intan Pariwara, 1988.

[43] Syah, Muhibbin. Psikologi Pendidikan dangan Pendekatan Terpadu, Bandung: Remaja Rosdakarya, 2004.

[44] Tafsir, Akhmad. IImu Pendidikan Islam Perspektif Islam, Bandung : PT.Remaja Rosdakarya, 2010.

[45] Tim Pakar Yayasan Jati Diri Bangsa, Pendidikan Karakter di Sekolah Dari Gagasan Ke Tindakan, Jakarta : PT.Gramedia, 2011.

[46] Tim Penyusun kamus pusat pembinaan dan pengembangan bahasa, kamus 
besar bahasa indonesia, jakarta : balai pustaka, 1997.

[47] Ulwan, Abdul Nasih. Pendidikan Anak Menurut Islam, Kaidah-Kaidah Dasar, Bandung : PT. Remaja Rosdakarya, 1992.

[48] Undang-Undang Dasar Tahun 1945 Pasal 31 Ayat 3 